\title{
The Passivation Behavior of Carbon Steel Rods of Nepal in Different Media
}

\author{
J. Bhattarai*, A. Kafle and N. P. Bhattarai \\ Central Department of Chemistry, Tribhuvan University, GPO Box 2040, Kathmandu, Nepal \\ E-mail:bhattarai_05@yahoo.com
}

\begin{abstract}
The passivation behavior of carbon steel rods of Nepal is studied in $1 \mathrm{M} \mathrm{HCl}, 0.5$ $\mathrm{M} \mathrm{NaCl}$ and $1 \mathrm{M} \mathrm{NaOH}$ solutions at $25^{\circ} \mathrm{C}$, open to air using corrosion tests and electrochemical measurements. The corrosion rate of all the examined steel rods is significantly lower in $1 \mathrm{M} \mathrm{NaOH}$ solution (about $10^{-3} \mathrm{~mm} / \mathrm{y}$ ) than those in $0.5 \mathrm{M} \mathrm{NaCl}$ (about $10^{-2} \mathrm{~mm} / \mathrm{y}$ ) and $1 \mathrm{M} \mathrm{HCl}$ (about $10^{1}-10^{2} \mathrm{~mm} / \mathrm{y}$ ) solutions. The corrosion rate of SR71 steel rod is remarkably lower $(3.65 \mathrm{~mm} / \mathrm{y})$ than those of other four different steel rods $\left(3-4 \times 10^{2} \mathrm{~mm} / \mathrm{y}\right)$ of Nepal in $1 \mathrm{M} \mathrm{HCl}$ solution. The ennoblement of the open circuit potentials of all the examined steel rod specimens is clearly observed in $1 \mathrm{M} \mathrm{NaOH}$ solution than those in $0.5 \mathrm{M} \mathrm{NaCl}$ and $1 \mathrm{M} \mathrm{HCl}$ solutions. The open circuit potentials of the steel rods are in the passive potential regions of the iron wire in $1 \mathrm{M} \mathrm{NaOH}$ solution. Therefore, steel rods of different companies of Nepal showed significantly high corrosion resistance in $1 \mathrm{M} \mathrm{NaOH}$ solution at $25^{\circ} \mathrm{C}$.
\end{abstract}

\section{Introduction}

The corrosion of steels is a problem of enormous practical importance because, steels represent the largest single class of alloys in use worldwide. Corrosion of steels is becoming a big problem since the beginning of $20^{\text {th }}$ century because of the widely use of steels as structural materials. It is believed that only the carbon steel, approximately $85 \%$ of the annual steel production of the world, is widely used as engineering material in marine applications, nuclear power and fossil fuel power plants, chemical processing, petroleum production and refining, transportation, pipelines, mining, metal-processing equipment, construction and so on. These are the reasons for the existence of entire industries devoted to provide the corrosion protective systems for steels and irons. The long term durability of new steel structures and the remaining life of existing steel structures is of central interest to their proper maintenance and asset management. This is particularly the case where protective measures of corrosion such as paint coatings, galvanizing or cathodic protection methods are becoming ineffective. To address such corrosion prevention problems, recent research has produced better quality models for the progression of corrosion of steels with time. These employ fundamental characteristics 
of steels corrosion as obtained from actual field observations and from laboratory-based electrochemical and other observations.

New corrosion problems are arising with the widespread use of different types of steels in various environments up to now. In the 1970s when instruments for surface analysis became available, many corrosion studies had performed by using the surface analysis techniques. ${ }^{1-8}$ The electrochemical measurements have been reported to study the corrosion behavior of steels in alkaline solutions ${ }^{9-11}$ and in $\mathrm{NaCl}$ solutions. ${ }^{12-16}$ However, there is no any research works on the corrosion behavior of steels produced or/and used in Nepal. In this context, it is very interesting to study the passivation behavior of various carbon steel rods of Nepal in different environments.

The main aim of this research work is to study the passivation behavior of the carbon steel rods produced in Nepal for construction purposes, in acidic $1 \mathrm{M} \mathrm{HCl}$, neutral $0.5 \mathrm{M}$ $\mathrm{NaCl}$ and alkaline $1 \mathrm{M} \mathrm{NaOH}$ solutions at $25^{\circ} \mathrm{C}$, open to air using corrosion tests and electrochemical measurements.

\section{Experimental Methods}

Various carbon steel rods of Nepal, with the average composition (wt \%, about: $\mathrm{C}=$ 0.17 to $0.25 ; \mathrm{Si}=0.40 ; \mathrm{Mn}=0.90 ; \mathrm{S}=0.05 ; \mathrm{P}=0.05$ and the rest iron, were used in this study. The steel rod samples obtained from different companies are named as SR71, SR72, SR73, SR74 and SR75. Prior to the corrosion tests and electrochemical measurement, steel rods having about 7-8 $\mathrm{mm}$ diameter of the different steel factories of Nepal were mechanically polished to a mirror finish using edge cutting machine and silicon carbide paper up to grit number 1000 in cyclohexane, degreased with acetone and dried in air.

The corrosion rate of the steel rod specimens was estimated from the weight loss after immersion for 190-264 hours in $100 \mathrm{~mL}$ of $1 \mathrm{M} \mathrm{HCl}, 0.5 \mathrm{M} \mathrm{NaCl}$ and $1 \mathrm{M} \mathrm{NaOH}$ solutions at $25^{\circ} \mathrm{C}$, open to air. The open circuit potentials of the steel rod specimens were measured after immersion for 2 hours in $1 \mathrm{M} \mathrm{HCl}, 0.5 \mathrm{M} \mathrm{NaCl}$ and $1 \mathrm{M} \mathrm{NaOH}$ solutions at $25^{\circ} \mathrm{C}$, open to air. The cathodic and anodic potentiostatic polarization measurements were also carried on a steel wire of Nepal in $1 \mathrm{M} \mathrm{NaOH}$ solution at $25^{\circ} \mathrm{C}$. A platinum mesh and saturated calomel electrode were used as counter and reference electrodes, respectively. The sample specimens were used as a working electrode. The potential given in this paper is relative to saturated calomel electrode (SCE).

\section{Results and Discussion}

Figures 1(a), 1(b) and 1(c) show the corrosion rates of five carbon steel rods produced by five different steel companies of Nepal, after immersion in $1 \mathrm{M} \mathrm{HCl}, 0.5 \mathrm{M} \mathrm{NaCl}$ and $1 \mathrm{M} \mathrm{NaOH}$ solutions, respectively at $25^{\circ} \mathrm{C}$, open to air. In $1 \mathrm{M} \mathrm{HCl}$, the corrosion rates 
of all the examined steel rods are in the range of about $10^{1} \mathrm{~mm} / \mathrm{y}$. Among these five different steel rods, sample SR71 of the company one shows the lowest corrosion rate of about $3.65 \mathrm{~mm} / \mathrm{y}$ which is nearly one order of magnitude lower than those of the corrosion rates of samples of other four different companies ( that is, SR72, SR73, SR74 and SR75). The corrosion rates of the SR73 and SR74 samples are slightly higher than those of the SR72 and SR75 samples in $1 \mathrm{M} \mathrm{HCl}$ solution $25^{\circ} \mathrm{C}$. This trend of the different corrosion rates of the steel rods of different companies of Nepal is not clearly observed in neutral $0.5 \mathrm{M} \mathrm{NaCl}$ and alkaline $1 \mathrm{M} \mathrm{NaOH}$ solutions at $25^{\circ} \mathrm{C}$. In $0.5 \mathrm{M}$ $\mathrm{NaCl}$, all five different steel rods show the almost same corrosion rates (that is, between 6.1 to $8.6 \times 10^{-2} \mathrm{~mm} / \mathrm{y}$ ) after immersion for eleven days. The sample SR74 shows slightly higher corrosion rate than others. Similarly, the corrosion rates of all five different steel rods are almost same corrosion rates (that is, $1.6-3.0 \times 10^{-3} \mathrm{~mm} / \mathrm{y}$ ) after immersion for 264 hours in alkaline $1 \mathrm{M} \mathrm{NaOH}$ solution at $25^{\circ} \mathrm{C}$. These results revealed that the corrosion rate of all examined carbon steel rods in $1 \mathrm{M} \mathrm{HCl}$ solution is significantly higher than those in $0.5 \mathrm{M} \mathrm{NaCl}$ and $1 \mathrm{M} \mathrm{NaOH}$ solutions. All the examined steel rods of different companies of Nepal show very high corrosion resistance in $1 \mathrm{M} \mathrm{NaOH}$ solution at $25^{\circ} \mathrm{C}$.

Electrochemical measurements were carried out for a better understanding of the passivation behavior of the steel rods of Nepal after immersion for 2 hours in acidic $1 \mathrm{M}$ $\mathrm{HCl}$, neutral $0.5 \mathrm{M} \mathrm{NaCl}$ and alkaline $1 \mathrm{M} \mathrm{NaOH}$ solutions at $25^{\circ} \mathrm{C}$, open to air. Figures 2(a) and 2(b) show the changes in open circuit potentials of samples SR71 and SR72, respectively with immersion time for 2 hours in $1 \mathrm{M} \mathrm{HCl}, 0.5 \mathrm{M} \mathrm{NaCl}$ and $1 \mathrm{M} \mathrm{NaOH}$ solutions at $25^{\circ} \mathrm{C}$. In both steel rod samples, the open circuit potentials in $1 \mathrm{M} \mathrm{HCl}, 0.5$ $\mathrm{M} \mathrm{NaCl}$ and $1 \mathrm{M} \mathrm{NaOH}$ solutions after immersion for about 30 minutes reach a steady state and almost same values of about $-460,-580$ and $-160 \mathrm{mV}$ (SCE), respectively. The nature of changes of the open circuit potentials of the steel rods with immersion time in acidic, neutral and alkaline solutions are not same. The changes in the open circuit potentials for the examined steel rods are not significant with immersion time in $1 \mathrm{M} \mathrm{HCl}$ solution. In $0.5 \mathrm{M} \mathrm{NaCl}$ solution, the open circuit potentials shifted to more negative (or less noble) direction with immersion time as shown in Figs 2(a) and 2(b). However, the open circuit potentials of the steel samples are sharply shifted to more positive (or more noble) direction with immersion time in alkaline $1 \mathrm{M} \mathrm{NaOH}$ solution as shown in Figs 2(a) and 2(b). Consequently, the open circuit potential of the steel rods is more negative value (i.e., about $-580 \mathrm{mV}, \mathrm{SCE}$ ) in $0.5 \mathrm{M} \mathrm{NaCl}$ solution than that in $1 \mathrm{M} \mathrm{HCl}$ solution. However, in $1 \mathrm{M} \mathrm{NaOH}$, the open circuit corrosion potential is more positive value (i.e., about $-160 \mathrm{mV}, \mathrm{SCE}$ ) than that in $0.5 \mathrm{M} \mathrm{NaCl}$ solution. These results revealed that steel rods are more passive in alkaline $1 \mathrm{M} \mathrm{NaOH}$ than those in acidic $1 \mathrm{M} \mathrm{HCl}$ and neutral 0.5 


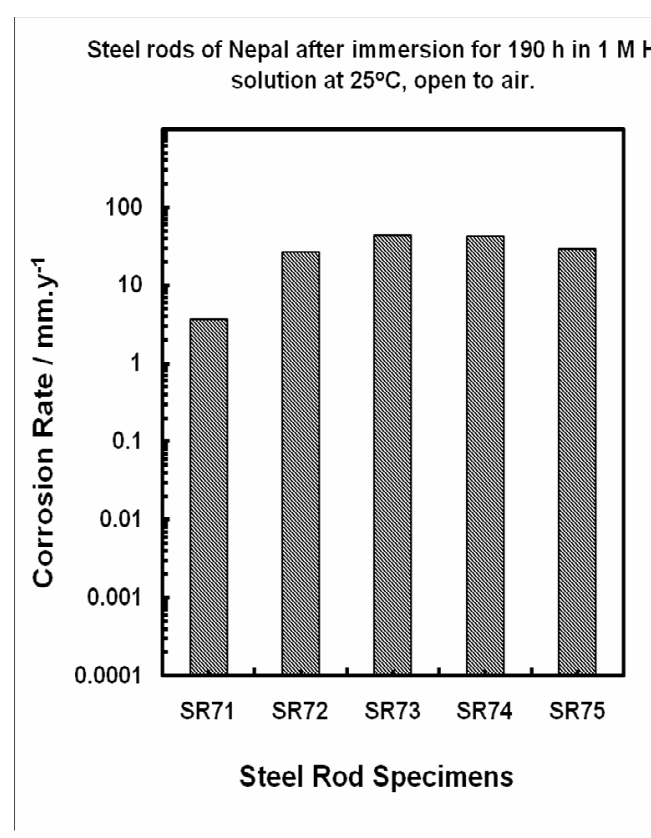

(a)

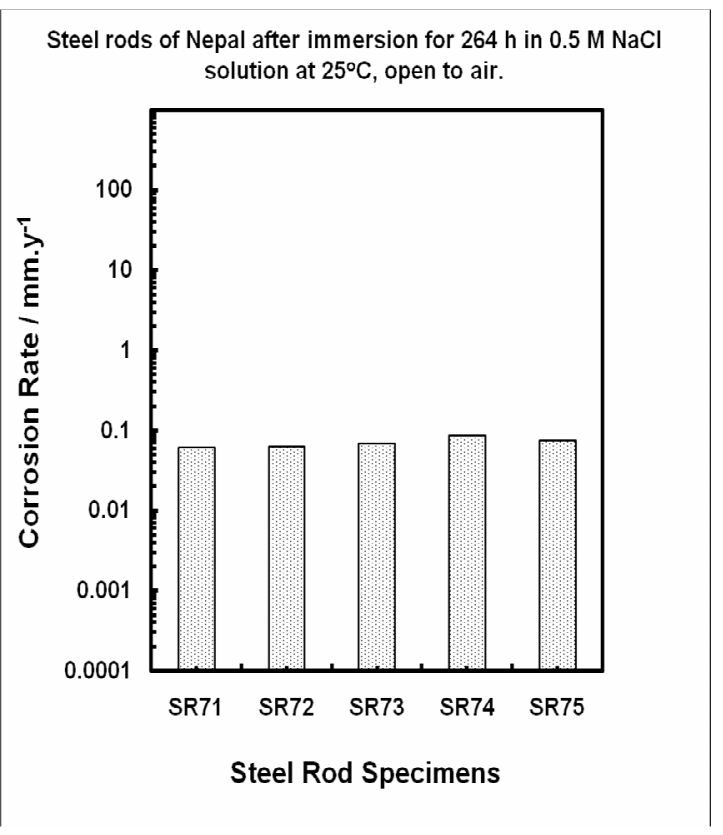

(b)

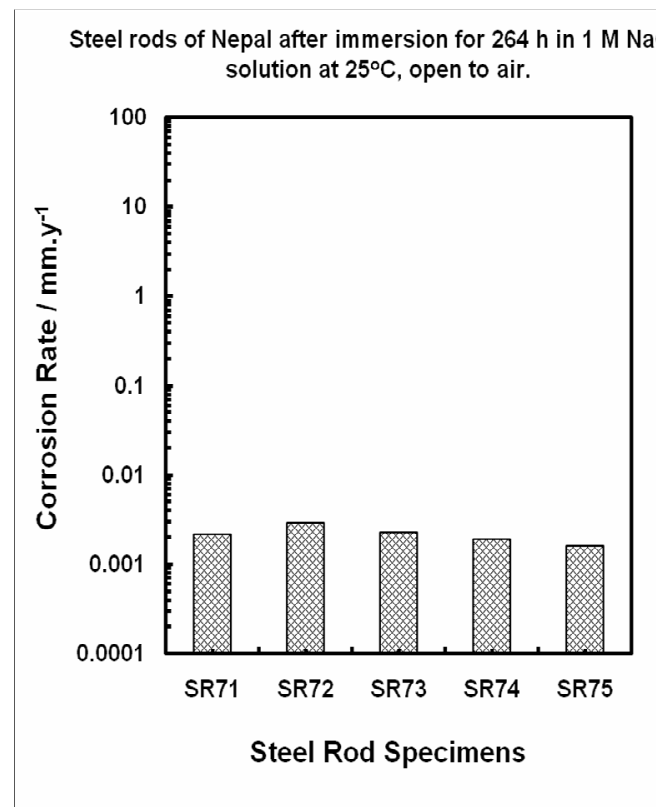

(c)

Figure 1: Corrosion rates of steel rods of different five companies of Nepal in (a) $1 \mathrm{M} \mathrm{HCl}$, (b) $0.5 \mathrm{M} \mathrm{NaCl}$ and (c) $1 \mathrm{M} \mathrm{NaOH}$ solutions at $25^{\circ}$, open to air. 


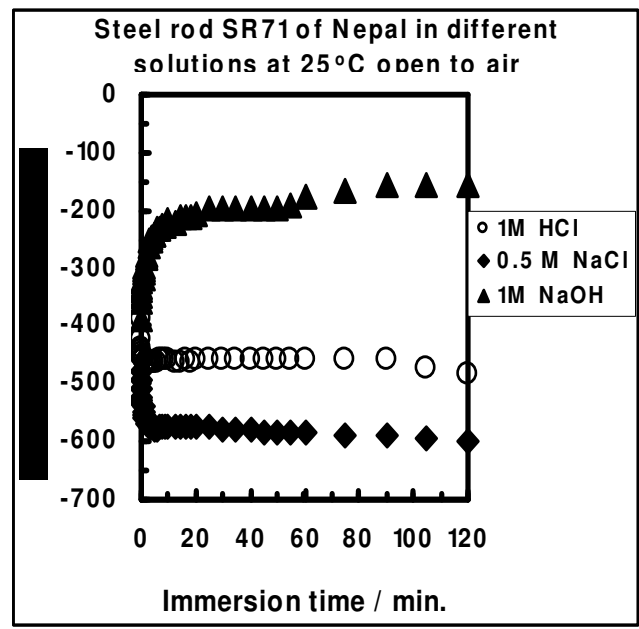

(a)

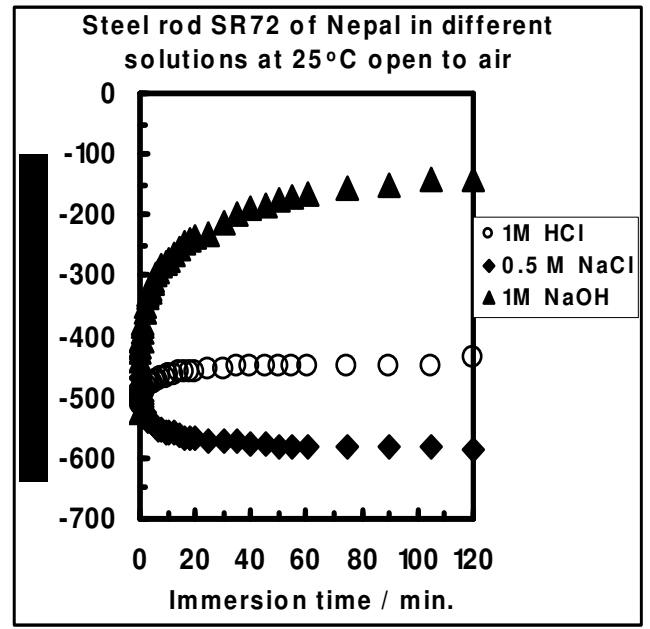

(b)

Figure 2: Changes in open circuit potentials for (a) SR71 and (b) SR72 steel rods of Nepal in different environments at $25^{\circ} \mathrm{C}$, open to air as a function of immersion time.

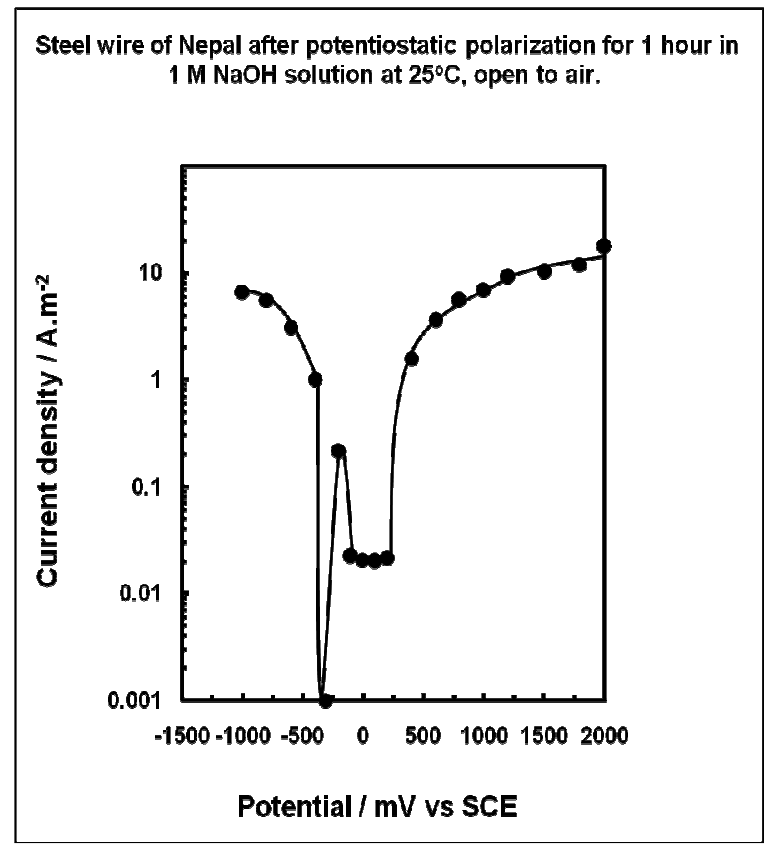

Figure 3: The potentiostatic polarization curve of the steel wire of Nepal in $1 \mathrm{M} \mathrm{NaOH}$ solution at $25^{\circ} \mathrm{C}$, open to air.

$\mathrm{M} \mathrm{NaCl}$ solutions. Furthermore, figure 3 shows the potentiostatic polarization curve for a steel wire after polarization for $1 \mathrm{~h}$ in alkaline $1 \mathrm{M} \mathrm{NaOH}$ solution at $25^{\circ} \mathrm{C}$. The steel wire shows clearly the active-passive transition and transpassivation. The steel wire is active at the potential range between -500 to $-200 \mathrm{mV}$ (SCE) while it is passive at the 
potential range between -150 to $250 \mathrm{mV}$ (SCE) in $1 \mathrm{M} \mathrm{NaOH}$ solution. The passive current density is in the range of $10^{-2} \mathrm{~A} / \mathrm{m}^{2}$ in $1 \mathrm{M} \mathrm{NaOH}$ solution. Transpassivity is clearly seen after polarization at $300 \mathrm{mV}$ (SCE) or more anodic potentials probably due to the formation of soluble ferrate $\left(\mathrm{FeO}_{4}{ }^{2-}\right)$ in $1 \mathrm{M} \mathrm{NaOH}$ solution. ${ }^{17}$ Consequently, the corrosion rates of steel rods are significantly higher in $1 \mathrm{M} \mathrm{HCl}$ than those in $0.5 \mathrm{NaCl}$ and $1 \mathrm{M} \mathrm{NaOH}$ solutions as shown in Fig. 1. This is mostly due to an ennoblement of the open circuit potentials of steel rods at passive potential regions (that is, between -150 to $250 \mathrm{mV}, \mathrm{SCE}$ ) in $1 \mathrm{M} \mathrm{NaOH}$ solution at $25^{\circ} \mathrm{C}$. Similarly, the open circuit potentials of the steel rods in $1 \mathrm{M} \mathrm{HCl}$ (that is, about $-460 \mathrm{mV}$, SCE) are in more active potential regions (that is, -500 to $-200 \mathrm{mV}$, SCE) of the steel wire in alkaline solution at $25^{\circ} \mathrm{C}$ as shown in Fig. 3.

\section{Conclusions}

The passivation behavior of the carbon steel rods of Nepal used mainly for construction purposes is studied in acidic $1 \mathrm{M} \mathrm{HCl}$, neutral $0.5 \mathrm{M} \mathrm{NaCl}$ and alkaline $1 \mathrm{M}$ $\mathrm{NaOH}$ solutions at $25^{\circ} \mathrm{C}$, open to air by corrosion tests and electrochemical measurements. The following conclusions are drawn:

1. The corrosion rate of the steel rods of Nepal in $1 \mathrm{M} \mathrm{HCl}$ is significantly higher than those in $0.5 \mathrm{M} \mathrm{NaCl}$ and $1 \mathrm{M} \mathrm{NaOH}$ solutions. The corrosion rates of different steel rods of Nepal are not same in acidic solution. However, the corrosion rates of all the examined steel rods are almost in the same range in neutral and alkaline solutions, respectively.

2. The open circuit potentials of the carbon steel rods are located in the passive potential regions of steel wire in alkaline $1 \mathrm{M} \mathrm{NaOH}$ solution while the open circuit potentials of steel rods are located in the active regions of the steel wire in neutral $0.5 \mathrm{M} \mathrm{NaCl}$ solution.

\section{Acknowledgments}

Authors are thankful to the Head, Central Department of Chemistry, Tribhuvan University, Nepal for providing us the available research facilities to conduct this research work. An appreciation goes to Mr. Lalanath Subedi, Asstt. Dean, Institute of Engineering, Tribhuvan University for providing facilities of the edge cutting machine.

\section{References}

1. Holliday, J. E. and Frankenthal, R. P., J. Electrochem. Soc., 1972, 119, 11901192. 
2. Asami, K., Hashimoto, K. and Simodaira, S., Corros. Sci., 1978, 18, 151-160.

3. Zou, J. -Y. and Chin, D. -T., Electrochimica Acta, 1987, 32, 1751-1756.

4. Kamimura, T. and Stratmann, M., Corros. Sci., 2001, 43, 429-447.

5. Olsson, C. -O. A and Landolt, D., Electrochimica Acta, 2003, 48, 1093-1104.

6. Shibata, T., Corros. Sci., 2007, 49, 20-30.

7. Fujimoto, S. and Tsuchiya, H., Corros. Sci., 2007, 49, 195-202.

8. Yang, S. and Macdonald, D. D., Electrochimica Acta, 2007, 52, 1871-1879.

9. Abdul Azim, A. A., Anwar, M. M. and Sanad, S. H., Corros. Sci., 1969, 9, 405412.

10. Newman, J. E., Corros. Sci., 1981, 21, 487-503.

11. Gonzalez, J. A., Miranda, J. M., Otero, E. and Felius, S., Corros. Sci., 2007, 49, 436-448.

12. Wendt, J. L. and Chin, D. -T.,Corros. Sci., 1985, 25, 889-900.

13. Nishikata, A., Yamashita, Y., Katayama, H., Tsuru, T., Usami, A., Tanabe, K. and Mabuchi, H.,Corros. Sci., 1995, 37, 059-2069.

14. Melchers, R. E. and Asce, M.,J. infrastruct. Syst., 2006, 12, 54-162.

15. Reffass, M., Sabot, R., Savall, C., Jeannin, M., Creus, J. and Refait, Ph., Corros. Sci., 2006, 48, 709-26.

16. Isaacs, H. S., Looi, Y. M. and de Wit, J. H. W.,Corros. Sci., 2007, 49, 53-62.

17. Uhlig, H. H. and Revie, R. W., in Corrosion and Corrosion Control, $3^{\text {rd }}$ edition, 1991, p.97. 